\title{
Eservice Quality For Customer Satisfaction Measurement: A Case Study On Islami Bank Bangladesh Ltd.
}

\section{A. M. Shahabuddin}

Associate Professor, DBA, International Islamic University Chittagong, BANGLADESH

\begin{abstract}
The purpose of the study is to identify customer satisfaction through e-service quality of Islami Bank Bangladesh Limited (IBBL). Buckley (2003:455) defines eService as the electronic provision of a service to customers whilst Santos (2003:234) describes e-service as the provision of consumers with a superior experience with respect to the interactive flow of information. The researchers used judgment sampling. Customers faced ATM service disorder, problems in using using sms banking services, prompt service from the bank. User-friendly, responsive online service experiences, educating customer how to use online service, training of employees will increase the e-service quality of IBBL in future.
\end{abstract}

Key words: E-service Quality Dimensions, GAP model, Customer satisfaction, Banks JEL Classification Code: M3

\section{INTRODUCTION}

Zeithaml's (2002:135) research on electronic service quality indicates that E-S-Q has seven dimensions from two scales: a core E-S-Q scale and a E-RecS-Q scale. Four dimensions efficiency, reliability, fulfillment and privacy form the core E-S-Q scale that can be used to measure customer perceptions of service quality. According to Zeithaml (2002:136) the other three dimensions become salient when online customers run into problems. These three dimensions are responsiveness, compensation and contact. These three dimensions were conceptualized by the research as constituting Electronic Recovery Service Quality (E-RecS-Q).

Objectives of the study are:

- To describe the E-SQ, E-RecS-Q scale for measuring the E-service Quality.

- To evaluate the existing model of service quality

- To recommend some suggestions to overcome the gap between service quality and customer expectation.

\section{Methodology Of THE Study}

Primary data has been collected from discussion with the relevant officials of Chittagong. The secondary data sources are annual reports, manuals, and brochures of Islami Bank Bangladesh Limited (IBBL).Questionnaire is based on E-S-Q scale method \& E-RecS-Q scale method. It is close 
ended, structured based question. Total 150 questionnaires have been sent but only 100 respondents properly response. The data then tabulated and prepared the paper.

\section{LITERATURE REVIEW}

Zeithaml (2002:137) identifies the four key dimensions of quality as efficiency, reliability, fulfillment and privacy and then defines electronic service quality (e-SQ) as the extent to which a Website facilitates effective and efficient shopping, purchasing and delivery. By implication online systems quality refers to satisfaction delivered by the system's ease of use and usefulness. The incubation dimension lists the determinants of a Website daily hit rate and the time length any visitor stays on the Website as ease of use, appearance, linkages, content and layout. Santos (2003:239) defines these determinants as follows:

- $\quad$ Ease of use is defined as how easy the Website is for customers to conduct external search in cyberspace and internal navigation and search within the Website.

- Appearance is defined by Santos (2003:239) as the proper use of color, graphics, images and animations, together with the appropriate size of the Web pages. Appearance is usually the first thing observed by Web users.

- $\quad$ Linkages refer to the number and quality of links that a Website offers.

- Structure and layout refers to the organization and presentation of a Website's content and information. This structure is characterized by simplicity clarity, consistent layout, good use of frame, provision of a site map that allows users to skip sections that are of no interest, a clear listed menu, and the company logo being present are some of the key factors that impact on structure and layout.

- Content refers to the presentation and layout of factual information and function on a Website.

\section{Discussions}

\section{E-S-Q scale dimensions with related questions (variables) Factors under the Efficiency Dimension}

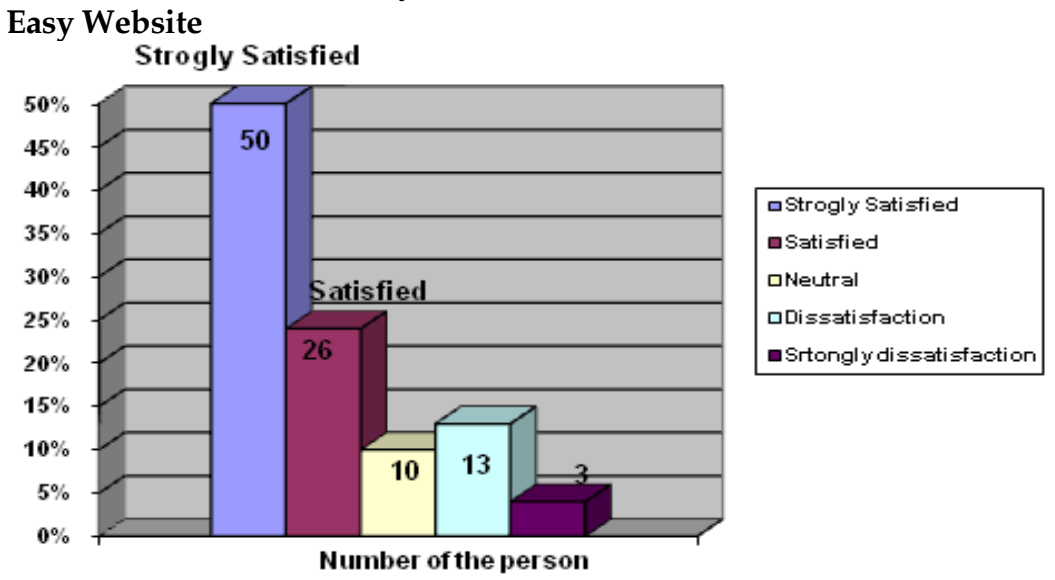

Figure: Ease of use IBBL Website; Source: Field survey

From the bar Figure it was found that $50 \%$ of the respondents felt it easy \& mostly satisfied, $26 \%$ respondents were only satisfied, $10 \%$ were neutral, $13 \%$ were dissatisfied \& $3 \%$ were strongly dissatisfied. 


\section{IBBLs Internet site is well organized}

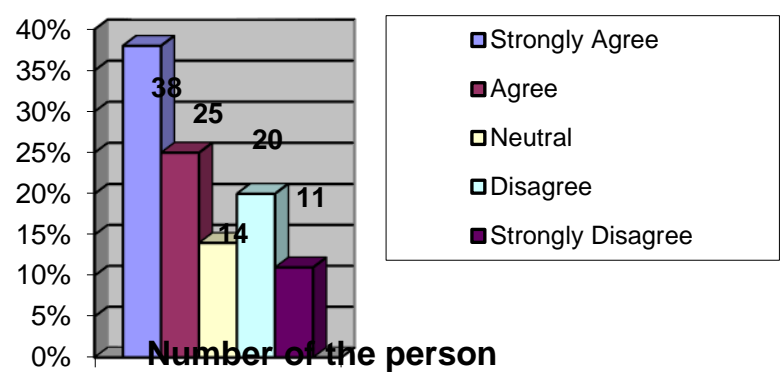

Figure : Well organized e-service site

From the bar Figure it was found that 38\% respondents felt IBBL Internet service site is well organized \& strongly agreed, $25 \%$ respondents were only agreed, $8 \%$ respondents were neutral, $20 \%$ respondents were disagreed \& $11 \%$ respondents were strongly disagreed about the Internet Islami Banking site.

\section{Effectiveness of IBBL Internet}

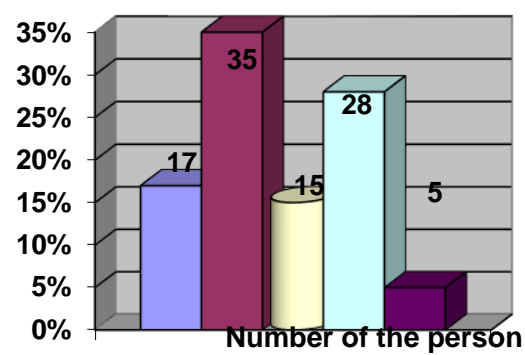

\begin{tabular}{|l}
\hline Strogly Satisfied \\
$\square$ Satisfied \\
$\square$ Neutral \\
$\square$ Dissatisfaction \\
$\square$ Srtongly dissatisfaction
\end{tabular}

Figure : The depth of IBBLs Internet Islami Banking functionality

In the figure, $17 \%$ of the respondents felt the depth of IBBLs Internet banking functionality is efficiently working \& strongly satisfied, $35 \%$ respondents were only satisfied, $15 \%$ respondents were neutral, $28 \%$ respondents were dissatisfied \& $5 \%$ respondents were strongly dissatisfied.

\section{Factors under reliability dimension}

IBBL Internet availability

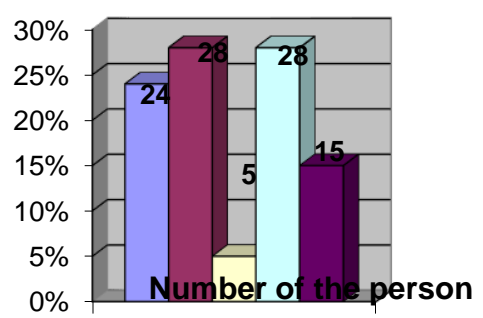

\begin{tabular}{|l|}
\hline QStrongly Agree \\
$\square$ Agree \\
$\square$ Neutral \\
$\square$ Disagree \\
$\square$ Strongly Disagree
\end{tabular}

Figure: Availability of prompt e-service

From the Figure it was found that $24 \%$ of the respondents felt IBBL Banking system being available at all times when needed \& strongly agreed of it, $28 \%$ respondents were only agreed, $5 \%$ respondents were neutral, $28 \%$ respondents were disagreed \& $15 \%$ respondents were strongly disagreed of it. 
IBBLs internet site do not freeze after entering the order information.

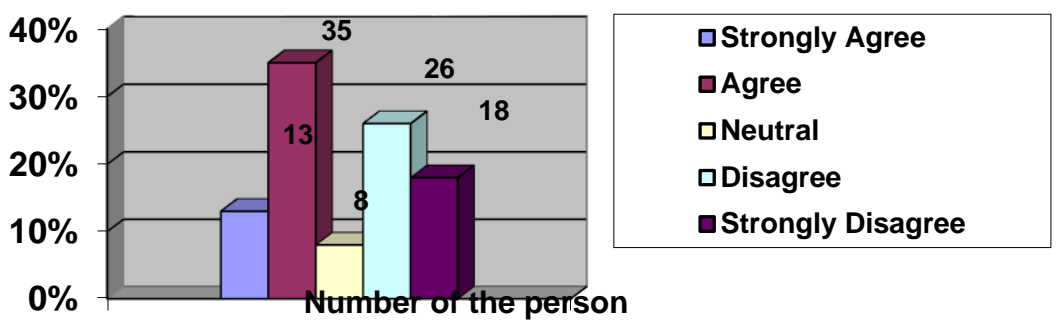

Figure: Freezing opportunity of Islami Banking website pages

From the bar Figure it was found that $13 \%$ of the respondents were strongly agreed, 35\% respondents were agreed, $8 \%$ were neutral, $26 \%$ were disagreed \& $18 \%$ were strongly disagreed about IBBL website pages were frozen after entering the order.

\section{Factors under fulfillment dimension:}

The IBBLs site makes accurate promises about the e-services delivered:

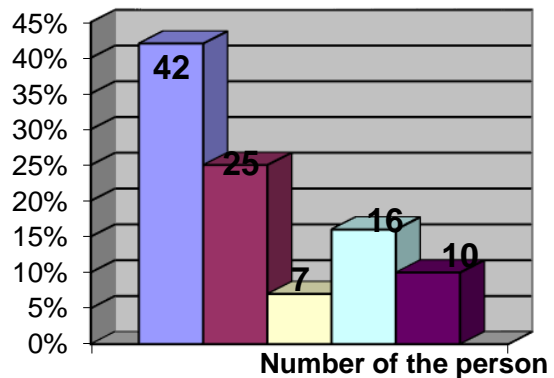

\begin{tabular}{|l|}
\hline$\square$ Strongly Agree \\
$\square$ Agree \\
$\square$ Neutral \\
$\square$ Disagree \\
$\square$ Strongly Disagree \\
\hline
\end{tabular}

Figure : Satisfaction Based on IBBL commitment; Source: Field survey

Most of (42\%)respondents strongly agreed \& satisfied with it, $25 \%$ respondents were agreed, $7 \%$ respondents were neutral, $16 \%$ respondents were disagreed \& $10 \%$ respondents were strongly disagreed \& felt dissatisfaction.

Accuracy of information:

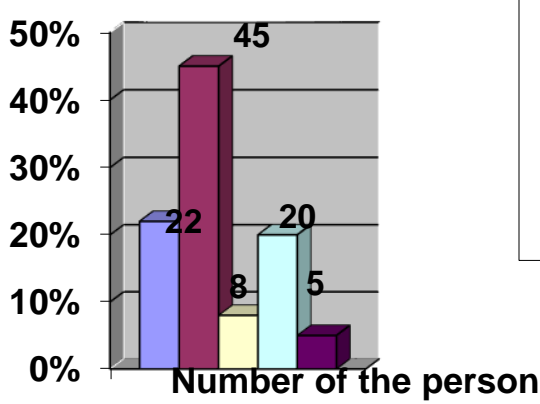

\begin{tabular}{|l|}
\hline SStrogly Satisfied \\
$\square$ Satisfied \\
$\square$ Neutral \\
$\square$ Dissatisfaction \\
$\square$ Srtongly dissatisfied
\end{tabular}

Figure : Accuracy of information Source: Field survey

Comment: $22 \%$ respondents were agreed \& felt IBBL e-service covers accuracy of information, $45 \%$ respondents were only agreed, $8 \%$ respondents were neutral, $20 \%$ respondents were disagreed \& $5 \%$ respondents were strongly disagreed of it. 


\section{Truthfulness about its offerings:}

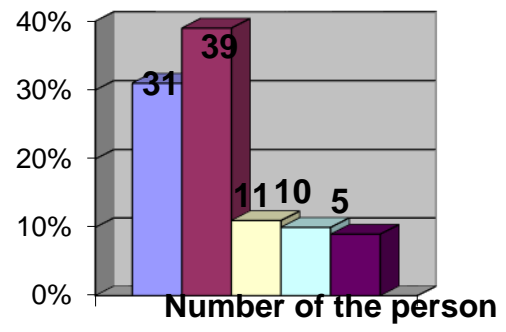

口Strongly Agree

aAgree

口Neutral

口Disagree

-Strongly Disagree

Figure : Truthful e-service offering; Source: Field survey

IBBLs e-service was truthful about its offering. Here, out of 100 respondents, 31\% respondents strongly agreed \& satisfied with it, 39\% respondents were only agree, $11 \%$ respondents were neutral, $10 \%$ respondents were dissatisfaction \& $5 \%$ respondents were strongly disagreed \& felt dissatisfaction.

\section{Factors under privacy dimension:}

Protects the personal information:

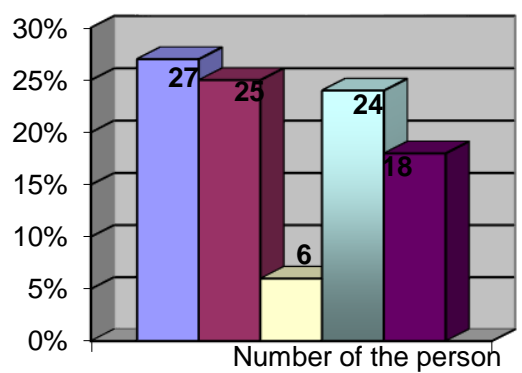

\begin{tabular}{|l|}
\hline$\square$ Strongly Agree \\
$\square$ Agree \\
$\square$ Neutral \\
口isagree \\
$\square$ Strongly Disagree \\
\hline
\end{tabular}

Figure: Protecting the personal Information; Source: Field survey

From the above Figure it was found that $27 \%$ of the respondents felt it protects the personal information \& strongly agreed, $25 \%$ respondents were agreed, $6 \%$ were neutral, $24 \%$ were disagreed \& $18 \%$ were strongly disagreed of it.

Accuracy \& safety:

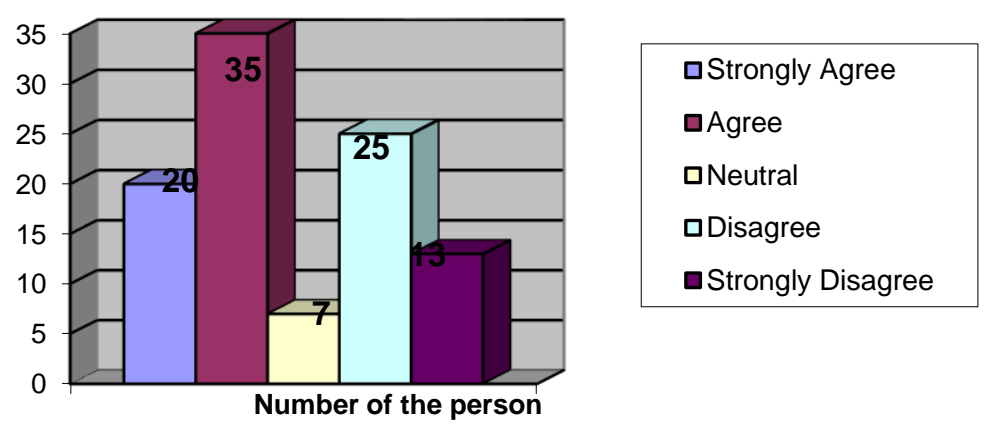

Figure : Transactions are accurate \& safe; Source: Field survey

Here, $20 \%$ respondents strongly agreed, $35 \%$ respondents were only agreed, $7 \%$ respondents were neutral, $25 \%$ respondents were disagreed \& $13 \%$ respondents were strongly disagreed \& felt dissatisfaction. 
Factors under e-recs-q scale dimensions with related questions (variables):

Factors under responsiveness dimension:

Satisfaction level in terms of problem solution:

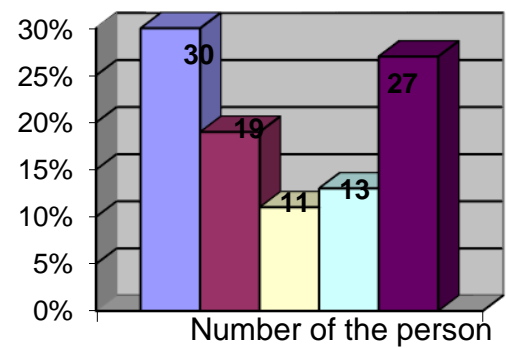

\author{
口Strogly Satisfied \\ 口Satisfied \\ 口Neutral \\ 口Dissatisfaction \\ 口Srtongly dissatisfaction
}

Figure: Satisfaction Level ; Source: Field survey

From the bar Figure it was found that $30 \%$ of the respondents felt IBBL can solve their problems \& they strongly satisfied, $19 \%$ respondents were only satisfied, $11 \%$ respondents were neutral, $13 \%$ respondents were dissatisfied \& $27 \%$ respondents were strongly dissatisfied \& they felt IBBL can't solve their problem.

IBBL provide instant customer feedback service through e-mail:

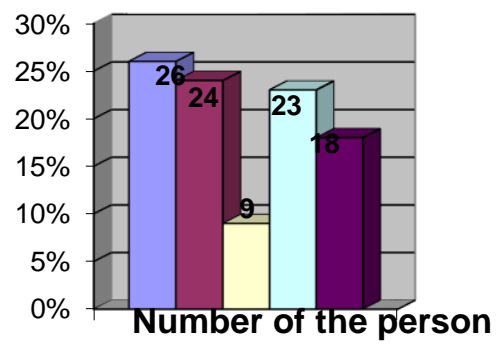

\begin{tabular}{|l|}
\hline$\square$ Strongly Agree \\
$\square$ Agree \\
$\square$ Neutral \\
$\square$ Disagree \\
$\square$ Strongly Disagree \\
\hline
\end{tabular}

Figure : Provide customer feedback services; Source: Field survey

Most $(26 \%)$ of the respondents felt IBBL provide instant customer feedback service \& they were strongly agreed, $24 \%$ respondents were agreed, $9 \%$ respondents were neutral, $23 \%$ respondents were dissatisfied \& $18 \%$ respondents were strongly dissatisfied of it.

\title{
Problems are resolved on time
}

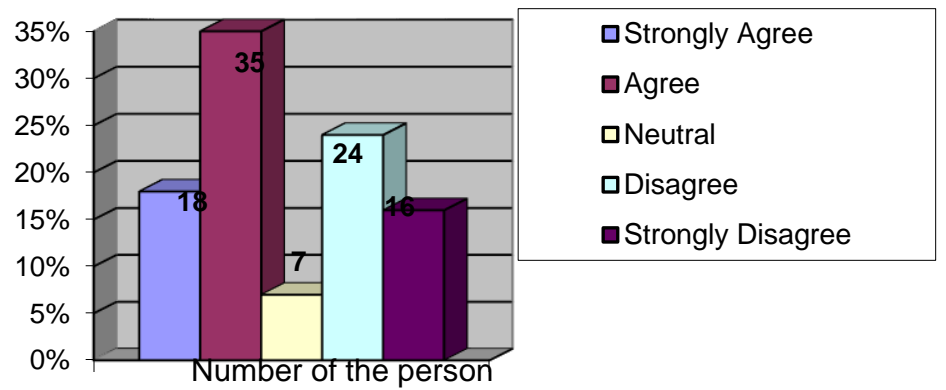

Figure : Problem resolving; Source: Field survey

From the bar Figure it was found that $18 \%$ of the respondents felt IBBL can resolve their problems on time \& they strongly agreed, 35\% respondents were only agreed, $7 \%$ respondents were neutral, $24 \%$ respondents were disagreed \& $16 \%$ respondents were strongly disagreed of it. 


\section{Factors under contact dimension:}

IBBL is easily accessible \& reachable:

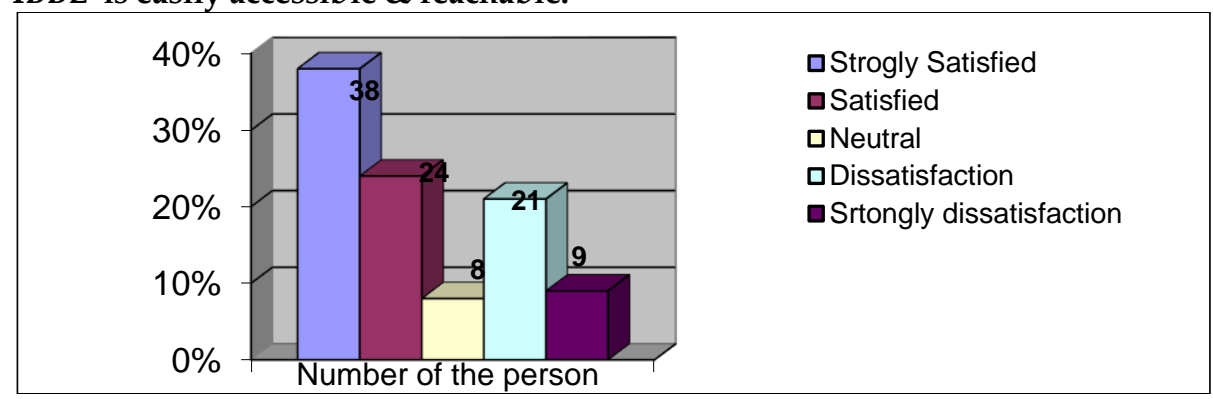

Figure : Ease of accessible; Source: Field survey

From the bar Figure it was found that $38 \%$ of the respondents felt IBBL being easily accessible \& Website provides a telephone number \& email to reach the IBBL \& they strongly satisfied, $24 \%$ respondents were only satisfied, $5 \%$ respondents were neutral, $21 \%$ respondents were dissatisfied \& $5 \%$ respondents were strongly dissatisfied.

\section{RECOMMENDATIONS}

In view of the above facts, the following recommendations are made to the respective concerned for consideration and implementation.

- Since $25 \%$ respondents were disagreed with the accuracy of IBBL automated service transactions. Hence automated service transactions should be more accurate to their customer.

- Sometimes the server may down or may not work at all. Users face problems while using sms banking, mobile banking

- To ensure proper online feedback to the customers on their requests.

- Since $26 \%$ were disagreed about IBBL compensation system. So, IBBL need to ensure that, it compensates properly \& quickly when transaction of amount is incorrect.

- IBBL management should emphasize on the responsiveness dimension to satisfy their customers.

- The officials should be trained up for maintaining the e-service factors.

- IBBL must always try to exceed the customers' expectations.

- IBBL need to emphasize on service recovery dimensions.

\section{Conclusions}

Customers' satisfaction is vastly dependent on e-service quality and E-S-Q \& E-RecS-Q scale is the method which evaluates the quality of the e-service. In reliability dimension, the most serious service gap is in performing customers' transactions at the right time. IBBL should search for the reasons of delays. In this respect, IBBL management has to increase the knowledge of the employees by providing training courses in their deficiency areas. However, attention needs to be given to the service recovery dimension of IBBL service which was identified as responsiveness. To gain the competitive advantages from his rivals the proposed model may play an enlighten role here. For further study on E-service quality a modified model or service recovery model may added the more values to distinct their service from other IBBLs. If those are followed and implemented, then it would surely help the IBBL in the near future furthermore and make its customers gain the utmost satisfaction. The winners in the online market space will be those who consistently provide compelling, user-friendly and responsive online service experiences. 


\section{REFERENCES}

A. Parasuraman, Valarie A. Zeithaml and Leonard L. Berry, (1985)A Conceptual Model of Service Quality and Its Implications for Future Research.The Journal of Marketing Vol. 49, No. 4 . pp. 41-50.

Adrian Payne, The Essence of Services Marketing. pp: 214-225.

Akinci A, Aksoy S \& Atilgan E. (2004). Adoption of Internet banking amongst sophisticated consumer segments in an advanced developing country. The International Journal of IBBL Marketing, 22(3):212-232.

Hoq, Mohammad, Muslim Amin, and Nigar Rumki. (2011) "The Effect of Trust, Customer Satisfaction and Image on Customers' Loyalty in Islamic Banking Sector." South asian journal of management, pp 70-93.

Jessica Santos, (2003) "E-service quality: a model of virtual service quality dimensions", Managing Service Quality, Vol. 13 Issue: 3, pp.233 - 246

Johnston R. (1995). The determinants of service quality: satisfiers and dissatisfies. International Journal of Service Industry Management, 6(5):53-71. Available from Emerald: http:/ /www.emeraldinsight.com/ [Accessed: 24-05-2011].

Kang G \& James J. (2004), Service quality dimensions: an examination of Grönroos's service quality model. Managing Service Quality, 14 (4)266-277. Available from Emerald: http:/ / www.emeraldinsight.com/

Mukesh Kumar, Fong Tat Kee, Amat Taap Manshor, (2009) "Determining the relative importance of critical factors in delivering service quality of banks: An application of dominance analysis in SERVQUAL model", Managing Service Quality, Vol. 19 Iss: 2, pp. $211-228$

Parasuraman, A., Valarie A. Zeithaml, Arvind Malhotra. 2005. E-S-QUAL: A MultipleItem Scale for Assessing Electronic Service Quality. Journal of Service Research. 7 (3). 213-233

Robinson, G. 2000. Bank to the future. Internet Magazine.

The critical factors of customer-perceived Banking Automated Service Quality. Source: Mohammed Al-Hawari, Marketing Bulletin, 2005, 16, Article1

V A. Zeithaml and M J Bitner, Service Marketing, 4th Edition. 